\title{
Effect of Phosphorus and Bio-Organics on Yield and Soil Fertility Status of Mungbean [Vigna radiata (L.) Wilczek Under Semi- Arid Condition of Rajasthan, India
}

\author{
Irfan Mohammad ${ }^{1}$, B.L. $\operatorname{Yadav}^{1}$ and Atik Ahamad ${ }^{2 *}$ \\ ${ }^{1}$ Department of Soil Science and Agricultural Chemistry, S.K.N. College of Agriculture, Jobner - \\ 303329, Sri Karan Narendra Agriculture University, Jobner, Jaipur, Rajasthan, India \\ ${ }^{2}$ Department of Soil Science and Agricultural Chemistry, NDUA\&T Kumarganj-224229 \\ Faizabad (U.P.), India \\ *Corresponding author
}

\begin{abstract}
A B S T R A C T
Keywords

Mungbean, Uptake, Phosphorus Levels, Bio-organic and yield.

Article Info

Accepted: 22 February 2017 Available Online: 10 March 2017

A field experiment was conducted during Kharif season 2015. The results of the study indicated the application of phosphorus up to $40 \mathrm{~kg} \mathrm{P}_{2} \mathrm{O}_{5}$ ha $^{-1}$ recorded significantly higher number of pods per plant, number of seeds per pod and seed and straw yield, nitrogen, phosphorus and potassium uptake in seed and straw, protein content in seed, microbial biomass carbon, nitrogen and phosphorus in soil as compared to absolute control and $20 \mathrm{~kg}$ $\mathrm{P}_{2} \mathrm{O}_{5}$ ha $^{-1}$ but was at par with $60 \mathrm{~kg} \mathrm{P}_{2} \mathrm{O}_{5} \mathrm{ha}^{-1}$. Application of $40 \mathrm{~kg} \mathrm{P}_{2} \mathrm{O}_{5} \mathrm{ha}^{-1}$ represented an increase of grain yield over control and $20 \mathrm{~kg} \mathrm{P}_{2} \mathrm{O}_{5}$ ha $^{-1}$ by 32.15 and 7.48 per cent, respectively. Application of PM @ $5 \mathrm{t} \mathrm{ha}^{-1}+$ Rhizobium +PSB significantly increased the pods per plant, number of seeds per pod and seed and straw yield, nitrogen, phosphorus and potassium content in seed and straw and their total uptake, protein content in seed, microbial biomass carbon, nitrogen and phosphorus in soil over control, PM@ $2.5 \mathrm{t} \mathrm{ha}^{-1}$, PM@ $5 \mathrm{t} \mathrm{ha}^{-1}$ and PM @ $2.5 \mathrm{tha}^{-1}+$ Rhizobium +PSB. The application of bio-organics on grain yield was found significant and all the treatments of bio-organics were differed significantly. The application of PM @ $5 \mathrm{t} \mathrm{ha}^{-1}+$ Rhizobium +PSB significantly higher the grain yield over control, PM @ $2.5 \mathrm{t} \mathrm{ha}^{-1}$, PM @ $5 \mathrm{t} \mathrm{ha}^{-1}$ and PM @ $2.5 \mathrm{t} \mathrm{ha}^{-1}+$ Rhizobium +PSB.PM applied @ $5 \mathrm{t} \mathrm{ha}^{-1}+$ Rhizobium + PSB significantly increased the grain yield by 52.63, 25.17, 7.15 and 15.20 per cent over $\mathrm{B}_{0}, \mathrm{~B}_{1}, \mathrm{~B}_{2}$ and $\mathrm{B}_{3}$, respectively.
\end{abstract}

\section{Introduction}

Greengram [Vigna radiata (L.) Wilczek] also known as mungbean is a self pollinated leguminous crop which is grown during kharif as well as summer seasons in arid and semi-arid regions of India. It is tolerant to drought and can be grown successfully on drained loamy to sandy loam soil in areas of erratic rainfall. The centre of origin of mungbean is India, may be used as a good quality green or dry fodder or green manure. Pulses accounts $24.79 \mathrm{~m}$ ha area with production of 19.77 million tonnes in the country. Mungbean stands third after chickpea and pigeon pea among pulses. It occupies 29.36 lakh hectare area and contributes 13.90 lakh tonnes in pulse production in the country (Anonymous, 201415). The important mungbean growing states 
are Rajasthan, Madhya Pradesh, Uttar Pradesh, Odisha, Maharastra, Karnataka and Bihar. In Rajasthan, total area under mungbean was 8.93 lakh hectares with the production of 4.23 lakh tonnes and productivity of $473 \mathrm{~kg} \mathrm{ha}$ (Anonymous, 2014-15). It is mainly cultivated in arid and semi arid districts including Nagaur, Jaipur, Jodhpur, Sikar, Pali, Jhunjhunu and Ajmer. Despite of being such an important crop, the average productivity of mungbean in the state is quite low compared to its production potential which is a matter of serious concern. Phosphorus is an important nutrient next to nitrogen for plants. Indian soils are poor to medium in available phosphorus. It is an indispensable, constituent of nucleic acid, ADP and ATP. It has beneficial effects on nodule stimulation, root development, growth and also hastens maturity as well as improves quality of crop produce. The study of phosphorus to legumes is more important than that of nitrogen as later is being fixed by symbiosis with rhizobium bacteria. Incorporation of poultry manure improve available nutrient status of the soil with enhanced soil biological activity which in turn provides a congenial physical condition and improved availability of nutrient in the rhizosphere thereby and ultimate by resulting in an improvement in the crop growth and providing a better source-sink relationship.

Phosphorus solubilizing microorganisms (bacteria and fungi) enable $\mathrm{P}$ to become available for plant uptake after solubilization. Several soil bacteria, particularly those belonging to the genera Bacillus and Pseudomonas and fungi belonging to the genera Aspergillus and Penicillium possess the ability to bring insoluble phosphates in soil into soluble forms by secreting organic acids such as formic, acetic, propionic, lactic, glycolic, fumaric, and succinic acids. These acids lower the $\mathrm{pH}$ and bring about the dissolution of bound forms of phosphates have reported that during the solubilization of rock phosphate by fungi, the $\mathrm{pH}$ of the culture was lowered from 7 to 3 . Some of the hydroxyl acids may chelate with calcium and iron resulting in effective solubilisation and utilization of phosphates. The phosphate solubilizing microorganisms improved phosphorus uptake over control with and without chemical fertilizers. There is lack of information on the use of PSM for mungbean under semi-arid region of Rajasthan, India. Therefore, a field experiment have been conducted to assess the role of phosphorus solubilizing microorganisms with different phosphorus levels on mungbean yield and nutrient uptake in Entisols under semi-arid region of Rajasthan, India.

\section{Materials and Methods}

A field experiment was conducted during the rainy (kharif) season of 2015 at Agronomy farm of SKN College of Agriculture, Jobner (Rajasthan) in western side at $26^{\circ} 05^{\prime}$ North latitude, $75^{\circ} 28^{\prime}$ East longitude and at an altitude of 427 metres above mean sea level. In Rajasthan, this region falls under Agro climatic zone III a (Semi-Arid Eastern Plain Zone) to study the effect of phosphorus and bio-organics on yield and soil fertility status. The experiment included 20 treatment combinations comprising 4 levels of phosphorus $\left(0,20,40\right.$, and $\left.60 \mathrm{~kg} \mathrm{ha}^{-1}\right)$ and five level of bio-organics ( control, PM @ 2.5 t ha ${ }^{-1}$, PM@5.0 ha $^{-1}$ t , PM@ $@ 2.5 \mathrm{t} \mathrm{ha}^{-1}+$ Rhizobium + PSB and PM @ 5.0 t ha ${ }^{-1}+$ Rhizobium + PSB) were replicated thrice in factorial randomized block design. Mungbean cv. RMG-492 after treated with Bavistin@ @ $\mathrm{g} \mathrm{kg}{ }^{-1}$ seed to control seed born disease fallowed by rhizobium culture@ $25 \mathrm{~g} \mathrm{~kg}^{-1}$ seeds. The seeds were inoculated with PSB @ $5 \mathrm{~g} \mathrm{~kg}^{-1}$ seed as per routine procedure 2-3 hours before sowing and dried in shade (Paul et al., 1971). The seeds were sown by 'pora' method with row spacing of $30 \mathrm{~cm}$ by hand plough at a depth of $5 \mathrm{~cm}$ using a seed rate of $20 \mathrm{~kg} \mathrm{ha}{ }^{-1}$. The variety RMG-492 of 
mungbean was used as the test crop and the sowing was done on $07^{\text {th }}$ July, 2015. Whole amount of poultry manure as per treatment was broadcasted uniformly one week before sowing and incorporated in the soil. The nutrient composition of poultry manure was $\mathrm{N}, \mathrm{P}$ and $\mathrm{K} 1.30 \%, 1.80 \%$ and 0.80 respectively. The experimental soil was loamy sand in texture, slightly alkaline in reaction $(\mathrm{pH} 8.20)$, poor in organic carbon $(0.18 \%)$ available nitrogen $\left(130.42 \mathrm{~kg} \mathrm{ha}^{-1}\right)$, available potassium (132.23 $\left.\mathrm{kg} \mathrm{K}_{2} \mathrm{O} \mathrm{ha}{ }^{-1}\right)$ and medium in phosphorus (15.95 $\left.\mathrm{kg} \mathrm{P}_{2} \mathrm{O}_{5} \mathrm{ha}^{-1}\right)$. The climate of this region is a typically semiarid, characterized by extremes of temperatures during both summers and winters. During summers the mean weekly weather parameters for the crop season recorded at college meteorological observatory have been depicted graphically in Fig 1.

\section{Soil sampling and analysis}

The Soil samples $(0-15 \mathrm{~cm})$ were collected at the beginning of experiment from whole field, and from each plot were taken after harvest of mungbean crop. The soil samples were sieved $(2 \mathrm{~mm})$, homogenized and stored at $4{ }^{0} \mathrm{C}$ for enzymatic activity estimation, while for chemical analysis, soil was air dried for 3 days and thereafter stored at room temperature.

Microbial biomass $\mathrm{C}$ by chloroform fumigation extraction method Vance et al., (1987) and microbial biomass $\mathrm{N}$ and $\mathrm{P}$ were estimated by chloroform fumigation extraction method Brookes et al., (1984). Soil dehydrogenase activity was estimated by measuring the rate of triphenylformazan (TPF) from triphenyl tetrazolium chloride (TTC) Casida et al., (1964) and alkaline phosphatase activities were measured by usingp-nitrophenyl (PNP) Tabatabai and Bremner (1969).

\section{Results and Discussion}

\section{Yield attributes and yield}

The increasing level of phosphorus significantly increased number of pods per plant and seeds per pod up to $40 \mathrm{~kg}_{2} \mathrm{O}_{5} \mathrm{ha}^{-1}$ but it was at par with $60 \mathrm{~kg} \mathrm{P}_{2} \mathrm{O}_{5} \mathrm{ha}^{-1}$ (Table 1). Application of $40 \quad \mathrm{~kg} \quad \mathrm{P}_{2} \mathrm{O}_{5} \quad \mathrm{ha}^{-1}$ representing an increase of number of pods per plant and seeds per pod by 34.97 and 14.06 per cent, 36.38 and 13.78 per cent over control and $20 \mathrm{~kg} \mathrm{P}_{2} \mathrm{O}_{5}$, respectively. These results are in close conformity with the findings of Yadav and Jakhar (2001), Tanwar et al., (2003) and Owla et al., (2007) in mungbean. Same table further indicated that application of bio-organics significantly increased the number of pods per plant and seeds per pod all the treatments of bioorganics differed significantly. Application of PM @ 5 t ha $^{-1}+$ Rhizobium +PSB recorded significantly higher the number of pods per plant by 37.35, 23.01, 6.77 and 14.21 per cent over $\mathrm{B}_{0}, \mathrm{~B}_{1}, \mathrm{~B}_{2}$ and $\mathrm{B}_{3}$, respectively. Application of PM @ $5 \mathrm{t} \mathrm{ha}^{-1}+$ Rhizobium +PSB significantly increased the seeds per pod over control, PM@2.5 t ha ${ }^{-1}$, PM @5 t $\mathrm{ha}^{-1}$ and PM @ $2.5 \mathrm{t} \mathrm{ha}^{-1}+$ Rhizobium +PSB representing an increase of 56.89, 28.60, 8.40 and 18.23 per cent, respectively. The availability and optimum supply of nutrients to plants favorably influenced the flowering and grain formation, which in turn increased the pods plant ${ }^{-1}$, grains pod ${ }^{-1}$ and test weight. Findings of Mathur et al., (2003) and Bhatt et al., (2013) in greengram.

The application of phosphorus up to $40 \mathrm{~kg} \mathrm{ha}^{-}$ ${ }^{1}$ significantly increased the grain yield (1163 $\mathrm{kg} \mathrm{ha}^{-1}$ ) which was significantly superior over control and $20 \mathrm{~kg} \mathrm{P}_{2} \mathrm{O}_{5} \mathrm{ha}^{-1}$ but remained at par with $60 \quad \mathrm{~kg} \quad \mathrm{P}_{2} \mathrm{O}_{5} \mathrm{ha}^{-1}$ (Table 1). Application of $40 \mathrm{~kg} \mathrm{P}_{2} \mathrm{O}_{5} \mathrm{ha}^{-1}$ represented an increase of grain yield over control and $20 \mathrm{~kg}$ $\mathrm{P}_{2} \mathrm{O}_{5}$ ha $^{-1}$ by 32.15 and 7.48 per cent, respectively. This might be fact that excess 
assimilates stored in the leaves and later translocated into grains at the time of senescence, ultimately led to higher grain yield. It was noted that a unit increase in number of pods/plant, number of grains/pod, test weight and total $\mathrm{N}, \mathrm{P}$ and $\mathrm{K}$ uptake increased grain yield of mungbean. These results are in close conformity with the findings of Yadav and Jakhar (2001), Tanwar et al., (2003) and Owlae $t$ al., (2007) in mungbean.

The application of bio-organics on grain yield $\left(1273 \mathrm{~kg} \mathrm{ha}^{-1}\right)$ was found significant and all the treatments of bio-organics were differed significantly. The application of PM @ $5 \mathrm{tha}$ ${ }^{1}+$ Rhizobium +PSB significantly higher the grain yield over control, PM @ $2.5 \mathrm{t} \mathrm{ha}^{-1}$, PM @ $5 \mathrm{t} \mathrm{ha}^{-1}$ and PM @ $2.5 \mathrm{t} \mathrm{ha}^{-1}+$ Rhizobium +PSB. PM applied@5 tha ${ }^{-1}+$ Rhizobium + PSB significantly increased the grain yield by $52.63,25.17,7.15$ and 15.20 per cent over $\mathrm{B}_{0}$, $\mathrm{B}_{1}, \mathrm{~B}_{2}$ and $\mathrm{B}_{3}$, respectively. The beneficial response of organic manure to yield might be attribute to the availability of sufficient amount of plant nutrient throughout the growth period of crop resulting in better nutrient uptake, plant vigour and superior yield attributes (Chesti and Ali, 2012).

\section{Nutrient uptake by plant}

The increasing levels of phosphorus up to 40 $\mathrm{kg} \mathrm{P}_{2} \mathrm{O}_{5}$ ha $^{-1}$ Significant increase in Total N, P and $\mathrm{K}$ uptake by grain and straw were recorded maximum with the application of $\mathrm{PM} @ 5 \mathrm{t} \mathrm{ha}^{-1}+$ Rhizobium + PSB as compared to $\left(20 \mathrm{~kg} \mathrm{P}_{2} \mathrm{O}_{5} \mathrm{ha}^{-1}\right.$ ) and control which at par with $60 \mathrm{~kg} \mathrm{P}_{2} \mathrm{O}_{5}$ ha $^{-1}$ (Table 2). The maximum total NPK uptake were 99.44, $8.52,85.38 \mathrm{~kg} \mathrm{ha}^{-1}$ and protein content $22.44 \%$ in mungbean seed were registered with application $\mathrm{P}_{60}\left(60 \mathrm{~kg} \mathrm{P}_{2} \mathrm{O}_{5} \mathrm{ha}^{-1}\right)$. uptake of nutrients is the function of their concentration in plant and grain and straw yields, the higher concentration of these nutrients coupled with significantly higher grain and straw yield improved the total uptake of N, P and K. Protein concentration is essentially the manifestation of $\mathrm{N}$ concentration in grain. Hence, increased $\mathrm{N}$ concentration might have also enhanced the protein content. These results corroborate the findings of Singh et al., (2009), Awomyet al., (2012) and Kumawat et al., (2014) in greengram.

Significant increase total N, P and K in grain and straw at harvest were recorded maximum with the application of PM @ $5 \mathrm{t} \mathrm{ha}^{-1}+$ Rhizobium + PSB as compared to control, PM @2.5 t ha ${ }^{-1}$, PM @ $5 \mathrm{t} \mathrm{ha}^{-1}$ and PM @2.5 t $\mathrm{ha}^{-1}+$ Rhizobium +PSB. The favorable soil conditions under organic manuring which acts as store house of energy for micro organisms are responsible for nutrient transformation besides providing better soil physicochemical environment (decrease in bulk density and increase in saturated hydraulic conductivity and CEC) which help in the minerlization of nutrients. The organic manures besides being the direct source of nutrients also solublized the insoluble $\mathrm{P}$ and $\mathrm{K}$ in soil through release of various organic acids (Dhakshinamoorthy et al., 2000). The increased availability of these nutrients in the root zone coupled with increased metabolic activity at cellular levels might have increased nutrient uptake and their accumulation in the vegetative plants. An improved metabolism to greater translocation of these nutrient to reproductive organs of the crop and ultimately increased the content in grain and straw. Inoculation of seed with Rhizobium + PSB along with PM @ $5 \mathrm{t} \mathrm{ha}^{-1}$ was more beneficial in enhancing all the above parameters due to increased solubility of phosphorus and higher $\mathrm{N}$ - fixation in nodules, leading to increased availability of $\mathrm{N}$ and $\mathrm{P}$. The Increase availability of $\mathrm{N}$ and $\mathrm{P}$ also helped to utilize more potassium from the soil by the plant. Thus, the greater content and uptake of $\mathrm{N}, \mathrm{P}$ and $\mathrm{K}$ in grain and straw as well as increase in protein content in grain might be due to 
synergistic effect of Rhizobium +PSB inoculations and higher $\mathrm{N}, \mathrm{P}$ and $\mathrm{K}$ content in poultry manure. These results corroborate the finding of Tanwar et al., (2003) in black gram and Basu et al., (2006) in groundnut.

Table.1 Effect of phosphorus and bio-organics on yield and yield attributes of mungbean crop

\begin{tabular}{|c|c|c|c|}
\hline Treatments & $\begin{array}{c}\text { Grain yield } \\
\mathrm{kg} \mathrm{ha}^{-1}\end{array}$ & $\begin{array}{c}\text { Number of pods } \\
\text { per plant }\end{array}$ & $\begin{array}{c}\text { Seeds per } \\
\text { pod }\end{array}$ \\
\hline \multicolumn{4}{|l|}{ Phosphorus levels } \\
\hline $\mathrm{P}_{0}$ (Control) & 880 & 25.65 & 7.20 \\
\hline $\mathrm{P}_{20}\left(20 \mathrm{~kg} \mathrm{P}_{2} \mathrm{O}_{5} \mathrm{ha}^{-1}\right)$ & 1082 & 30.35 & 8.63 \\
\hline $\mathrm{P}_{40}\left(40 \mathrm{~kg} \mathrm{P}_{2} \mathrm{O}_{5} \mathrm{ha}^{-1}\right)$ & 1163 & 34.62 & 9.82 \\
\hline $\mathrm{P}_{60}\left(60 \mathrm{~kg} \mathrm{P}_{2} \mathrm{O}_{5} \mathrm{ha}^{-1}\right)$ & 1209 & 36.15 & 10.16 \\
\hline SEm \pm & 25.01 & 0.70 & 0.23 \\
\hline $\mathrm{CD}(\mathrm{P}=0.05)$ & 71.61 & 2.01 & 0.66 \\
\hline \multicolumn{4}{|l|}{ Bio-organics } \\
\hline $\mathrm{B}_{0}$ (Control) & 834 & 26.50 & 6.82 \\
\hline $\mathrm{B}_{1}$ (Poultry manure $\left.(\mathrm{PM}) @ 2.5 \mathrm{t} / \mathrm{ha}\right)$ & 1017 & 29.59 & 8.32 \\
\hline $\mathrm{B}_{2}$ (Poultry manure (PM)@ $\left.5.0 \mathrm{t} / \mathrm{ha}\right)$ & 1188 & 34.09 & 9.87 \\
\hline $\mathrm{B}_{3}(2.5 \mathrm{t} / \mathrm{ha} \mathrm{PM}+$ Rhizobium $+\mathrm{PSB})$ & 1105 & 31.87 & 9.05 \\
\hline $\mathrm{B}_{4}(5.0 \mathrm{t} / \mathrm{ha} \mathrm{PM}+$ Rhizobium $+\mathrm{PSB})$ & 1273 & 36.40 & 10.70 \\
\hline SEm \pm & 27.97 & 0.79 & 0.26 \\
\hline $\mathrm{CD}(\overline{\mathrm{P}}=0.05)$ & 80.07 & 2.25 & 0.73 \\
\hline
\end{tabular}

Table.2 Effect of phosphorus and bio-organics on number of pods per plant and seeds per pod

\begin{tabular}{|c|c|c|c|c|}
\hline \multirow[t]{2}{*}{ Treatments } & \multicolumn{3}{|c|}{$\begin{array}{l}\text { Total nutrient uptake by grain } \\
\text { and straw }\left(\mathrm{kg} \mathrm{ha}^{-1}\right)\end{array}$} & \multirow{2}{*}{$\begin{array}{l}\text { Protein } \\
\text { content } \\
(\%)\end{array}$} \\
\hline & $\mathrm{N}$ & $\mathrm{P}$ & $\mathrm{K}$ & \\
\hline \multicolumn{5}{|l|}{ Phosphorus levels } \\
\hline $\mathrm{P}_{0}(\mathrm{Control})$ & 51.84 & 4.88 & 42.81 & 18.44 \\
\hline $\mathrm{P}_{20}\left(20 \mathrm{~kg} \mathrm{P}_{2} \mathrm{O}_{5} \mathrm{ha}^{-1}\right)$ & 78.07 & 6.64 & 67.65 & 20.50 \\
\hline $\mathrm{P}_{40}\left(40 \mathrm{~kg} \mathrm{P}_{2} \mathrm{O}_{5} \mathrm{ha}^{-1}\right)$ & 94.33 & 7.56 & 80.98 & 22.19 \\
\hline $\mathrm{P}_{60}\left(60 \mathrm{~kg} \mathrm{P}_{2} \mathrm{O}_{5} \mathrm{ha}^{-1}\right)$ & 99.44 & 8.52 & 85.38 & 22.44 \\
\hline SEm \pm & 2.20 & 0.32 & 1.63 & 0.50 \\
\hline $\mathrm{CD}(\overline{\mathrm{P}}=0.05)$ & 6.28 & 0.92 & 4.67 & 1.42 \\
\hline \multicolumn{5}{|l|}{ Bio-organics } \\
\hline $\mathrm{B}_{0}$ (Control) & 46.84 & 3.87 & 43.97 & 16.04 \\
\hline $\mathrm{B}_{1}$ (Poultry manure $\left.(\mathrm{PM}) @ 2.5 \mathrm{t} / \mathrm{ha}\right)$ & 70.33 & 5.77 & 61.85 & 19.43 \\
\hline $\mathrm{B}_{2}$ (Poultry manure (PM)@ 5.0 t/ha) & 95.14 & 8.11 & 79.88 & 23.01 \\
\hline $\mathrm{B}_{3}(2.5 \mathrm{t} / \mathrm{ha} \mathrm{PM}+$ Rhizobium $+\mathrm{PSB})$ & 82.77 & 6.98 & 70.79 & 21.29 \\
\hline $\mathrm{B}_{4}(5.0 \mathrm{t} / \mathrm{ha} \mathrm{PM}+$ Rhizobium $+\mathrm{PSB})$ & 109.50 & 9.29 & 89.53 & 24.68 \\
\hline SEm \pm & 2.45 & 0.36 & 1.82 & 0.55 \\
\hline $\mathrm{CD}(\overline{\mathrm{P}}=0.05)$ & 7.03 & 1.03 & 5.22 & 1.59 \\
\hline
\end{tabular}


Table.3 Effect of phosphorus and bio-organics on microbial biomass, enzyme activity and microbial population in soil

\begin{tabular}{|c|c|c|c|c|c|c|c|}
\hline \multirow[t]{2}{*}{ Treatments } & \multicolumn{3}{|c|}{$\begin{array}{l}\text { Microbial biomass } \\
\left(\mu \mathrm{g} \mathrm{g}^{-1}\right) \text { soil }\end{array}$} & \multirow{2}{*}{$\begin{array}{l}\text { Dehydro } \\
\text { genase } \\
(\mu \mathrm{g} \text { TPF } \\
\mathrm{g}^{-1} \text { soil } \\
\left.24 \mathrm{~h}^{-1}\right)\end{array}$} & \multirow{2}{*}{$\begin{array}{c}\text { Alkaline } \\
\text { phosphatase } \\
\text { enzyme } \\
(\mu \mathrm{g} \text { PNP produced } \\
\left.\mathrm{g}^{-1} \text { soil }^{-1}\right)\end{array}$} & \multirow{2}{*}{$\begin{array}{l}\text { Rhizob } \\
\text { ium } \\
\left(\times 10^{3}\right. \\
\text { cfu g }^{-1} \\
\text { soil) }\end{array}$} & \multirow{2}{*}{$\begin{array}{l}\text { PSB } \\
\left(\begin{array}{ll}x & 10^{2} \\
\mathrm{cfu} \mathrm{g}^{-1} \\
\text { soil })\end{array}\right.\end{array}$} \\
\hline & $\mathrm{C}$ & $\mathrm{N}$ & $\mathrm{P}$ & & & & \\
\hline \multicolumn{8}{|c|}{ Phosphorus levels } \\
\hline $\mathrm{P}_{0}$ & 176.58 & 35.44 & 28.45 & 115.85 & 9.66 & 9.10 & 13.85 \\
\hline $\mathrm{P}_{20}$ & 201.54 & 40.94 & 30.88 & 124.33 & 10.61 & 10.22 & 15.91 \\
\hline $\mathrm{P}_{40}$ & 222.54 & 45.58 & 32.97 & 132.28 & 11.35 & 11.25 & 17.78 \\
\hline $\mathrm{P}_{60}$ & 229.54 & 47.54 & 34.85 & 133.81 & 11.55 & 11.35 & 18.98 \\
\hline SEm \pm & 5.15 & 1.17 & 0.65 & 2.76 & 0.24 & 0.23 & 0.41 \\
\hline $\mathrm{CD}(\overline{\mathrm{P}}=0.05)$ & 14.74 & 3.34 & 1.86 & 7.92 & 0.70 & 0.67 & 1.18 \\
\hline \multicolumn{8}{|l|}{ Bio-organics } \\
\hline $\mathrm{B}_{0}$ & 162.99 & 33.12 & 26.17 & 107.38 & 8.55 & 8.53 & 11.67 \\
\hline $\mathrm{B}_{1}$ & 192.20 & 38.37 & 29.69 & 117.59 & 10.10 & 9.67 & 15.57 \\
\hline $\mathrm{B}_{2}$ & 227.62 & 46.86 & 34.35 & 135.90 & 11.79 & 11.42 & 18.65 \\
\hline $\mathrm{B}_{3}$ & 210.16 & 42.39 & 32.17 & 126.99 & 10.92 & 10.53 & 17.17 \\
\hline $\mathrm{B}_{4}$ & 244.78 & 51.13 & 36.56 & 144.97 & 12.61 & 12.25 & 20.08 \\
\hline $\mathrm{SEm} \pm$ & 5.76 & 1.30 & 0.73 & 3.09 & 0.27 & 0.26 & 0.46 \\
\hline $\mathrm{CD}(\overline{\mathrm{P}}=0.05)$ & 16.48 & 3.73 & 2.08 & 8.85 & 0.78 & 0.75 & 1.32 \\
\hline
\end{tabular}

Fig.1 Mean weakly meteorological data for crop season (Kharif, 2015)

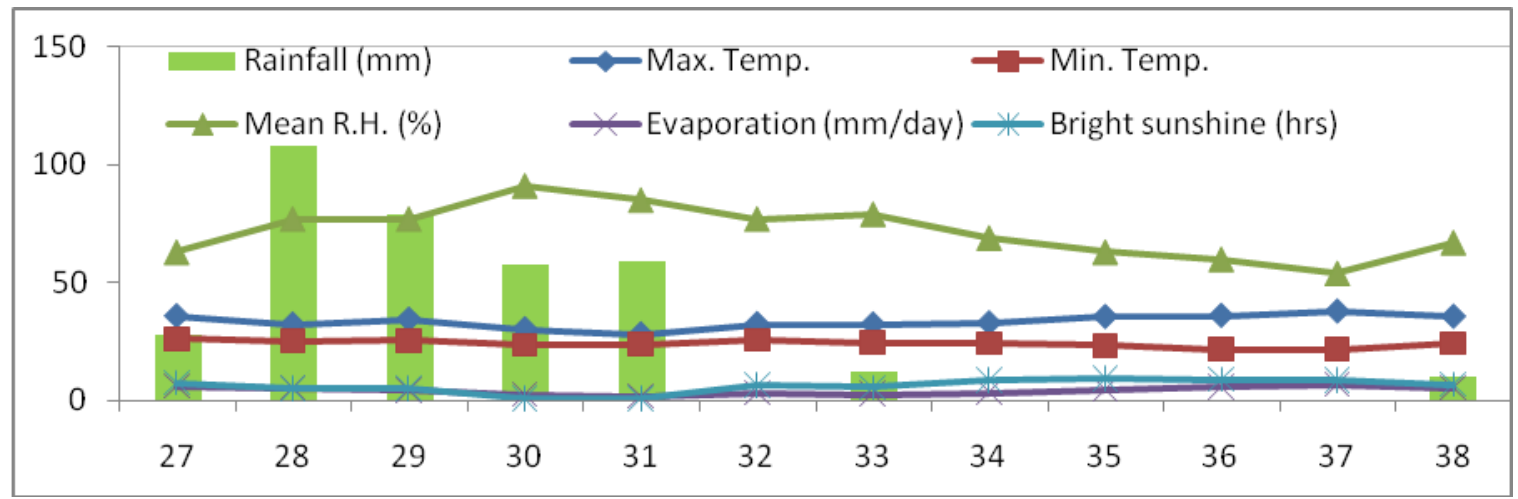

\section{Microbial biomass in soil}

Application of $40 \mathrm{~kg} \mathrm{P}_{2} \mathrm{O}_{5} \mathrm{ha}^{-1}$ significantly increased the microbial biomass carbon, nitrogen, phosphorus after harvest by 26.02 and $10.41 \%, 28.61$ and $12.32 \%, 22.49$ and $12.85 \%$ over control and $20 \mathrm{~kg} \mathrm{P}_{2} \mathrm{O}_{5} \mathrm{ha}^{-1}$, respectively (Table 3). However the application of $40 \mathrm{~kg} \mathrm{P}_{2} \mathrm{O}_{5} \mathrm{ha}^{-1}$ found at par with $60 \mathrm{~kg} \mathrm{P}_{2} \mathrm{O}_{5} \mathrm{ha}^{-1}$. The microbial biomass carbon increased with increase in dose of inorganic fertilizers, may be due firstly to increase in microbial population (Hasebe et $a l ., 1985)$ and secondary to the formation of root exudates, mucigel soughed off cells and underground roots previous cut crops which also play an important role in increasing biomass carbon (Goyal et al., 1992). 
The application of bio-organics on microbial biomass carbon, nitrogen, phosphorus at harvest was found significant and all the treatments of bio-organics were differed significantly. The application of $\mathrm{B}_{4}(\mathrm{PM} @ 5 \mathrm{t}$ $\mathrm{ha}^{-1}+$ Rhizobium +PSB) increased the microbial biomass phosphorus at harvest over $\mathrm{B}_{0}, \mathrm{~B}_{1}, \mathrm{~B}_{2}$ and $\mathrm{B}_{3}$. The increase in microbial biomass $\mathrm{C}, \mathrm{N}$ and $\mathrm{P}$ and activities of enzymes might also be due to increase in organic carbon of soil on account of addition of bioorganic. These results find support from the results of Saini et al., (2005) and Kumar et al., (2007).

The application inorganic fertilizers resulted in significantly higher soil microbial biomass nitrogen content as compared to the rest of the treatments. The fertilizer in the present study apparently provided supply of nutrients in balanced proportion which was reflected in term of increasing amount of microbial biomass nitrogen, increase in biomass nitrogen has also been reported by Wang Shuping et al., (2013). Soil microbial biomass phosphorus recorded higher due to phosphorus application up to $60 \mathrm{~kg} \mathrm{P}_{2} \mathrm{O}_{5} \mathrm{ha}^{-1}$ after the harvest of mungbean. It provided substrates essential for microbial growth and activity, which in term was responsible for increase in the soil microbial biomass $P$. reason attributed in reduction death of microbial cells due to absence of any phosphate subtract. The addition of higher levels of phosphorus through external sources might have influenced the metabolism of micro-organism which is responsible for soil microbial biomass-P was reported by Santhy et al., (2004).

\section{Enzymes activity in soil}

The increasing levels of phosphorus significantly increased the dehydrogenase, alkaline phosphatase enzyme activity after harvest up to $40 \mathrm{~kg} \mathrm{P}_{2} \mathrm{O}_{5} \mathrm{ha}^{-1}$, being at par with $60 \mathrm{~kg} \mathrm{P}_{2} \mathrm{O}_{5} \mathrm{ha}^{-1}$ (Table 3). The effect of application of bio-organics on dehydrogenase and alkaline phosphatase enzyme activity was found significant and all the treatments of bioorganics were differed significantly. The application of poultry manure @ $5 \mathrm{t} \mathrm{ha}^{-1}+$ Rhizobium + PSB significantly increased the dehydrogenase and alkaline phosphatase enzyme activity over control, PM @ $2.5 \mathrm{t} \mathrm{ha}^{-}$ 1, PM@5 t ha ${ }^{-1}$ and PM @ $2.5 \mathrm{t} \mathrm{ha}^{-1}+$ Rhizobium + PSB.

It might be due to highest dehydrogenase and alkaline phosphatase enzyme activity of soil recorded with application of poultry manure @ $5 \mathrm{t} \mathrm{ha}^{-1}+$ Rhizobium + PSB. Soil enzyme activities increased by the incorporation of organic manure were also reported by Nannipieri et al., (1983). The increased activity has generally been attributed to increased microbial biomass resulting from organic matter enrichment in the soil. Increase in activity may be due to protection to the enzymes fraction upon increase in the soil humus content was also reported by Pareek and Yadav (2011) and Nath et al., (2012).

\section{Microbial population in soil}

The increasing levels of phosphorus up to 40 $\mathrm{kg} \mathrm{ha}^{-1}$ significantly increased the microbial population of Rhizobium $\left(11.25 \times 10^{2} \mathrm{cfu} \mathrm{g}^{-1}\right)$ and PSB $\left(17.88 \times 10^{2} \mathrm{cfu} \mathrm{g}^{-1}\right)$ at flowering stage, which was found at par with $60 \mathrm{~kg}$ $\mathrm{P}_{2} \mathrm{O}_{5} \mathrm{ha}^{-1}$. The microbial population count was maximum with the application of poultry manure@5 t ha ${ }^{-1}+$ Rhizobium + PSB. Rhizobium (12.25 x $10^{3} \mathrm{cfu} \mathrm{g}^{-1}$ soil) and PSB (20.08 x $10^{2} \mathrm{cfu} \mathrm{g}^{-1}$ soil) count at flowering stage in soil increased considerably due to the application of organic manures (Table 3). The availability of carbonaceous materials and substrates such as sugar, amino acids and organic acids to the soil from the decomposing organic materials and decay of roots under the plant canopy are important for supplying energy for microbial population (Bowen and Rovira, 1991). 


\section{References}

Achakzai, A.K.K. and Bangulzai, M.I. 2006. Effect of various levels of nitrogen fertilizer on the yield and yield attributes of pea (Pisum sativum L.) cultivars. Pak. J. Bot., 38: 331-40.

Awomi, T.A., Singh, A.K., Kumar, M. and Bordoloi, L.J. 2012. Effect of phosphorus, molybdenum and cobalt nutrition on yield and quality of Mungbean [Vigna radiata (L) Wilczek] in acidic soil of North - East India. Indian J. Hill Farming, 25(2): 22-26.

Barrios-Masias, F.H., Cantwell, M.I. and Jackson, L.E. 2011. Cultivar Anonymous, 2014-15. Directorete of Agriculture Statistics and Economics, Govt. of India, New Delhi.

Basu, M., Mondhal, P., Basak, R.K., Basu, T.K. and Mahapatra, S.C. 2006. Effect of cobalt, rhizobium and phosphobacterium inoculations on yield and nutrient uptake in summer groundnut (Archis hypogaea L.) on Alluvial soils. J. Indian Society of Soil Sci., 54: 60-64.

Bhatt, P.K., Patel, B.T., Raval, C.H., Vyas, K.G. and Ali, S. 2013. Productivity, quality, nutrient content and soil fertility of summer greengram [Vigna radiata $(\mathrm{L}$. Wilczek] as influenced by different levels of vermicompost and phosphorus with and without PSB. Int. J. Agri. Sci., 9(2): 659-662.

Bowen, G.D., Bevege, D.I. and Mosse, B. 1975. The phosphate physiology of vesicular arbuscular mycorrhizas. In: Endomycorrhizas, Eds. Sanders, F.E., Mosse, B. and Tinker, P.B. Academic Press, London: 241-260.

Brookes, P.C., Landman, A., Pruden, G. and Jenkinson, D.S. 1984. Chloroform fumigation and the release of soil nitrogen: a rapid direct extraction method to measure microbial biomass nitrogen in soil. Soil Biol. Biochem., 17: 837-842.

Casida, L.E., Klein, D.A. and Santoro, T., 1964. Soil dehydrogenase activity. Soil Sci., 98: 371-376.
Chesti, M.H. and Ali, Tahir, 2012. Rhizospheric micro-flora, nutrient availability and yield of green gram (Vigna radiate L.) as influenced by organic manures, phosphate solublizers and phosphorus levels in Alfisols. J. Indian Society of Soil Sci., 60: 25-29.

Dakshinamoorthy, M., Santhy, P., Selvi, D. and Mathan, K.K. 2000. Sustenance of crop productivity and soil fertility on an inceptisol in a long term fertilizer experiment. In: Proceeding International Conference on Managing National Resources for Sustainable Agricultural Production in the 21st Century. New Delhi, 3; 1336-1337.

Goyal, S., Mishra, M.M., Hoda, I.S., Singh, R., Beri, V., Choudhary, M.R., Sandhu, P. S., Pasricha, N. S. and Bajwa, M.S. 1992. Build up of microbial biomass win continuous use of inorganic fertilizers and organic amendents. Proceeding of the international symposium on nutrient management for sustained productivity, 2: 149-151.

Hasebe, A., Kanazara, S. and Takai, Y. 1985. Mincrobial biomass in paddy soil II. Microbial biomass measured by Jenkinson's fumigation method. Soil Sci. Plant Nutrient, 34: 349-359.

Kumar, P. Kathju, S., Panwar, J., Saini, V.K. and Tarafdar, J.C. 2007. Dehydragenase and phasphatase activities in soil under acid ecosystems as influenced by tillage, soil depth and crop rotation. J. Indian Society of Soil Sci., 55: 488-492.

Kumawat, S.R., Khistriya, M.K., Yadav, S.L. and Kumar, M. 2014. Effect of phosphorus fertilization on yield, nutrient content, uptake and quality of summer greengram [Vigna radiata (L) Wilczek]. Environ. Ecol., 32(2A): 785-788.

Mathur, K., Singh, V.P. and Singh, B.P., 2003. Effect of sources of starter nitrogen and Rhizobium inoculation on grain yield and economics of summer moongbean cultivation. Res. Crops, 4: 186-189.

Nannipieri, P.L., Muccini, L. and Ciardi, C. 1983. Microbial biomass and enzyme 
activities: Production and persistence, Soil Biol. Biochem., 15: 679-685.

Nath, D.J., Ozah, B., Baruah, R., Borah, D.K. and Gupta, M. 2012. Soil enzymes and microbial biomass carbon under rice-toria sequence as influenced by nutrient management. J. Indian Society of Soil Sci., 60: 20-24.

Pareek, N. and Yadav, B.L. 2011. Effect of orgnaic manure on soil physio-chemical properties soil microbial biomass and yield of mustard under irrigation of different residual sodium carbonate water. J. Indian Society of Soil Sci., 59: 336-342.

Saini, V. K., Bhandari, S. C., Sharma, S.K. and Tarafdar, J. C. 2005. Assessment of microbial biomass under integrated nutrient management in soybean-winter maize cropping sequence. J. Indian Society of Soil Sci., 53: 346-351.

Santhy, P., Vijila, K., Selvi, D. and Dhakshinamoorthy, M. 2004. Studies on soil microbial biomass $\mathrm{P}$, labile $\mathrm{P}$ and phosphate activity under continuous intensive cultivation in an inceptisol. Annals of Agri. Res., 25: 38-42.

Singh, S. R., Bhat, M. I., Wani, J. A. and Najar, G.R. 2009. Role of rhizobium and VAM fungi for improvement in fertility and yield of green gram under temperature conditions. J. Indian Society of Soil Sci., 57: 45-52.

Tabatabai, M. A. and Bremner, J. M., 1969. Use of p-nitrophenyl phosphate for assay of soil phosphatase assay. Soil Biol. Biochem., 1: 371-376.

Tanwar, S.P.S., Sharma, G.L. and Chahar, M.S. 2003. Effect of phosphorus and biofertilizers on yield, nutrient content and uptake by blackgram (Vigna mungo (L.) Hepper). Legume Res., 26: 39-41.

Vance, E.D., Brookes, P.C. and Jenkinson, D.S., 1987. An extraction method for measuring soil microbial biomass carbon. Soil Biol. Biochem., 19: 703-707.

Wang, S, Zhou, G., San, C., Jhan, Jiag, Y., Jiang, Y., Liu, X., Wang, S.P., Zhou, G.S., Sun, C.Z., Jiang, Y.M., Jiang, Y. and Liuxw, 2003. A study of the dyamics of nitrogen in soil microbial biomass and its biological availability. Plant Nutrition and Fertilizer Sci., 9: 87-90.

Yadav, B.L. and Jakhar, S.R. 2001. Effect of tillage and phosphorus fertilization on yield and water expense efficiency of rainfed mungbean. J. Indian Society of Soil Sci., 49: 193-194.

\section{How to cite this article:}

Irfan Mohammad, B.L. Yadav and Atik Ahamad. 2017. Effect of Phosphorus and Bio-Organics on Yield and Soil Fertility Status of Mungbean [Vigna radiata (L.) Wilczek Under Semi- Arid Condition of Rajasthan, India. Int.J.Curr.Microbiol.App.Sci. 6(3): 1545-1553.

doi: https://doi.org/10.20546/ijcmas.2017.603.177 